Fixed Point Theory, 19(2018), No. 2, 515-526

DOI: $10.24193 /$ fpt-ro.2018.2.41

http://www.math.ubbcluj.ro/ nodeacj/sfptcj.html

\title{
FIXED POINT RESULTS FOR ADMISSIBLE $\mathcal{Z}$-CONTRACTIONS
}

\author{
MARIJA CVETKOVIĆ*, ERDAL KARAPINAR** AND VLADIMIR RAKOČEVIĆ* \\ *University of Niš, Faculty of Sciences and Mathematics, Višegradska 33, 18000 Niš, Serbia \\ E-mails: marijac@pmf.ni.ac.rs, vrakoc@sbb.rs \\ ** Department of Mathematics, Atilim University, Incek, 06836 Ankara, Turkey \\ E-mail: erdalkarapinar@gmail.com
}

Abstract. In this paper, we present some fixed point results in the setting of a complete metric spaces by defining a new contractive condition via admissible mapping embedded in simulation function.

Key Words and Phrases: Contractive mapping, simulation function, admissible mapping.

2010 Mathematics Subject Classification: 46T79, 47H10, 54H25.

Authors' contributions. All authors contributed equally and significantly in writing this article. All authors read and approved the final manuscript.

\section{REFERENCES}

[1] H.H. Alsulami, E. Karapınar, F. Khojasteh, A.F. Roldán-López-de-Hierro, A proposal to the study of contractions in quasi-metric spaces, Discrete Dynamics in Nature and Society 2014, Article ID 269286, 10 pages.

[2] H. Argoubi, B. Samet, C. Vetro, Nonlinear contractions involving simulation functions in a metric space with a partial order, J. Nonlinear Sci. Appl., 8(2015), 1082-1094.

[3] R.M. Bianchini, M. Grandolfi, Transformazioni di tipo contracttivo generalizzato in uno spazio metrico, Atti Acad. Naz. Lincei, VII. Ser., Rend., Cl. Sci. Fis. Mat. Natur., 45(1968), 212-216.

[4] E. Karapınar, H.H. Alsulami, M. Noorwali, Some extensions for Geragthy type contractive mappings, J. Inequalities Appl., 303(2015).

[5] E. Karapinar, P. Kuman, P. Salimi, On $\alpha-\psi$-Meri-Keeler contractive mappings, Fixed Point Theory Appl., 94(2013).

[6] E. Karapinar, B. Samet, Generalized $\alpha$ - $\psi$-contractive type mappings and related fixed point theorems with applications, Abstr. Appl. Anal. (2012), Article ID 793486.

[7] F. Khojasteh, S. Shukla, S. Radenović, A new approach to the study of fixed point theorems via simulation functions, Filomat, 29(6)(2015), 1189-1194.

[8] O. Popescu, Some new fixed point theorems for $\alpha$-Geraghty contractive type maps in metric spaces, Fixed Point Theory Appl., 190(2014).

[9] P.D. Proinov, A generalization of the Banach contraction principle with high order of convergence of successive approximations, Nonlinear Anal., 67(2007), 2361-2369.

[10] P.D. Proinov, New general convergence theory for iterative processes and its applications to Newton Kantorovich type theorems, J. Complexity, 26(2010), 3-42. 
[11] S. Radenović, Z. Kadelburg, D. Jandrlić, A. Jandrlić, Some results on weak contraction maps, Bull. Iranian Math. Society, 38(2012), no. 3, 625-645.

[12] A.F. Roldán-López-de-Hierro, E. Karapınar, C. Roldán-López-de-Hierro, J. Martínez-Moreno, Coincidence point theorems on metric spaces via simulation functions, J. Comput. Appl. Math., 275(2015), 345-355.

[13] I.A. Rus, Generalized contractions and applications, Cluj University Press, Cluj-Napoca, 2001.

[14] B. Samet, Best proximity point results in partially ordered metric spaces via simulation functions, Fixed Point Theory Appl., 232(2015).

[15] B. Samet, C. Vetro, P. Vetro, Fixed point theorem for $\alpha-\psi$ contractive type mappings, Nonlinear Anal., 75(2012), 2154-2165.

Received: February 25, 2016; Accepted: April 10, 2016. 